\title{
REMOVAL OF EXCESSIVE NITROGEN AND PHOSPHORUS FROM URBAN WASTEWATER USING LOCAL MICROALGAL BLOOM
}

\author{
Sumaiya Nusrat Chaitee, Rudra Protap Biswas, Md. Imran Kabir* \\ Department of Civil and Environmental Engineering, Shahjalal University of Science and Technology, Sylhet- \\ 3114, Bangladesh.
}

Received: 29 May 2021

Accepted: 06 September 2021

\begin{abstract}
The organic content from urban wastewater is treated with various conventional processes efficiently. However, for biological treatment of secondary effluent containing excessive inorganic nitrogen and phosphorus, microalgae can be used. In this study, algal strains have been collected from locally available natural blooms and cultured in a BG-11 medium. Spirulina sp., the blue-green algae, dominant over the other species within the natural bloom, is applied in ten different dosages $(0.2-2.5 \mathrm{~g} / \mathrm{L})$ to the synthetic wastewater with a 3-day hydraulic retention time. The removal efficiency of nitrate, ammonia, and phosphate have been observed to be about $60 \%$, $30 \%$, and $54 \%$ respectively. The highest removal efficiency has been found at $2.5 \mathrm{~g} / \mathrm{L}$ of microalgae dose. Linear forms of Langmuir and Freundlich isotherms have been used for biosorption modeling, and both isotherms fit well with $R^{2}>60 \%$ and NRMSE $<11 \%$ in all cases. Additionally, the separation factor and the adsorption intensity represent the favorability of the biosorption process.
\end{abstract}

Keywords:Biosorption; Microalgae; Urban wastewater; Wastewater treatment.

\section{INTRODUCTION}

Water is a fundamental necessity for life. Every metabolism inside a body depends on water. However, only $2.66 \%$ of the total water resource is freshwater. For this reason, the conservation of freshwater sources has become a priority throughout the world. The qualitative and quantitative threats to water resources have been imposed due to man-made pollution. The urban municipal wastewater generally originated from domestic and community uses. An urban city having a population of 5,00,000 and water consumption of $0.2 \mathrm{td}^{-1}$ capita $^{-1}$, produces $85,000 \mathrm{td}^{-1}$ of wastewater approximately(Cai et al. 2013). The inorganic component of municipal wastewater contributes greatly to the accumulation of nitrogen and phosphorus in receiving water bodies. The source of nitrogen and phosphorus in municipal wastewater is various household activities (Abdel-Raouf et al. 2012).About 30-50\% of the phosphorus originated from human wastes such as feces, urine, and waste food. The remaining phosphorus content (about 50-70\%) comes from Detergents which are used for laundering of clothes (Barth et al. 1976).Initiating these pollutants into the environment without proper treatment has a significant negative impact on the aquatic ecosystem (Mennaa et al. 2015).Eutrophication is a common phenomenon causes due to an excess amount of nitrogen and phosphorus. Due to eutrophication, the growth of algae and higher forms of plants are accelerated. As a result of eutrophication, oxygen depletion and toxic effect occurs in the receiving water body along with several adverse ecological impacts and decreased lifespan of aquatic organisms (Henze et al. 2001). The water quality degrades gradually (Commission 2002). The area of surface water polluted with algal bloom is not suitable for uses such as drinking, irrigation, industry, recreation, or fishing (Carpenter et al. 1998). The toxic effect may enter into the food chain and causes various kind of diseases to human.

Aside from the imbalance in the aquatic ecosystem, humans and animals who depend on the water of receiving water bodies are facing a greater threat to their health. Exposure to an excess amount of Nitrate may cause gastric cancer, impose threats to the newborn child and pregnant ladies, and changes the composition of hemoglobin which is responsible for methemoglobinemia or blue baby syndrome in an infant (Ghafari et al. 2008, Mayo and Hanai 2014). Due to blue baby syndrome, respiratory problems, digestive problems like diarrhea, vomiting, and in extreme cases even death in young children may occur. Nitrate also has carcinogenic, teratogenic, and mutagenic properties (Abel 2014). Ammonia and Phosphorus donot have any direct effect on humans or animals. The necessity of removing them from municipal wastewater is protecting the food chain (Klaassen and Amdur 2013).

However, it is very difficult to find a solution for the treatment and safe discharge of wastewater. Since the solution involves integrated processes, the technical, economic, and financial issues must be considered. Activate sludge process is a very popular conventional method for wastewater treatment. This process shows ahigher removal of biodegradable material by using bacteria in primary and secondary treatments of effluent. This apparently clean 
secondary treated effluent contains a large number of inorganic compounds, like nitrogen and phosphorus. The disposal of a large volume of sludge is also troublesome and may lead to secondary pollution (Olguín 2012). The total cost of wastewater treatment increases for each additional step. For removing nitrates, ammonia, and phosphate from wastewater completely, a tertiary treatment process costs four times more than the primary treatment process. Lastly, the conventional treatment processes lead to incomplete utilization of natural resources (Molinos-Senante et al. 2010, Abdel-Raouf et al. 2012).

On the other hand, the capacity of microalgae for inorganic nutrient uptake is very high (Talbot and De la Noüe 1993, Blier et al. 1995). Numerous studies have shown that treating the wastewater with microalgae can decrease the nutrient concentrations up to 95\% (Arbib et al. 2014, Gao et al. 2016, Lavrinovičs and Juhna 2017, Wang et al. 2017). Therefore, as a potential alternative, wastewater treatment by using microalgae has been proposed as a tertiary treatment process (Olguín 2003, Sturm and Lamer 2011). Biological removal of nutrients using microalgae offers several advantages over tertiary chemical and physicochemical treatments (Proulx and De la Noue 1988, De la Noüe and Basseres 1989). Algal treatment is favorable because of the photosynthesis characteristics of algae. During photosynthesis, solar energy converts into useful biomasses by combining nutrients such as nitrogen and phosphorus and carbon-di-oxide from the environment (Martínez et al. 2000, Cai et al. 2013). It is a costeffective and environment-friendly method(Pittman et al. 2011). Microalgae also produce oxygen during the photosynthesis process and also have a disinfection effect due to elevated $\mathrm{pH}$ (Martínez et al. 2000). The main challenge for this technology lies in the wastewater composition, microalgae species, and the final utilization of biomass yield (Jais et al. 2017). The harvested microalgae can be used for the production of biofuel, fertilizers, various high-value products like Pharmaceuticals and genetically engineered products (Mallick 2002, Mennaa et al. 2015). These include antibacterial, antiviral, antitumor/ anticancer, antihistamine, and many other biologically valuable products (Borowitzka 2013). Blue-green algae are a prominent form of microalgae within the natural bloom in freshwater (Cai et al. 2013). They are also potential for the removal of inorganic nutrients from wastewater. It is also well established that blue-green algae are capable of reducing nitrate, ammonia and phosphate (Abdel-Raouf et al. 2012).

Nutrients from wastewater are generally uptake by algae for their cellular growth. For the growth of organisms, nitrogen is considered a critical nutrient. Within a cell of any organism, organic nitrogen is found in the form of biological substances. They are- peptides, proteins, enzymes, chlorophylls, energy transfer molecules (ADP, ATP), and genetic materials (RNA, DNA) (Barsanti and Gualtieri 2014). Microalgae convert inorganic nitrogen into organic nitrogen by the assimilation process. Eukaryotic algae perform the assimilation process by using nitrate, nitrite, and ammonium which are the forms of inorganic nitrogen (Cai et al. 2013). Inorganic phosphorus is also very important for microalgae growth and metabolism. It is found in nucleic acids, lipids, proteins, and the intermediates of carbohydrate metabolism. Phosphorus also helps to generation of ATP from adenosine diphosphate (ADP), accompanied by a form of energy input (Martinez et al. 1999, Wu et al. 2012, Beuckels et al. 2015, Whitton et al. 2015).

The efficiency of microalgae for removing nitrogen and phosphorus content from municipal wastewater has been shown in many studies. Chlorella vulgaris has an efficiency of removing $86 \%$ of inorganic nitrogen and $78 \%$ of inorganic phosphorus (Lau et al. 1997). About 97.8\% of phosphorus is removed from domestic sewage by algae (Colak and Kaya 1988, Abdel-Raouf et al. 2012). Another study shows that Chlorella vulgaris can remove ammonia and nitrogen completely from the wastewater. Whereas, the removal rate of phosphate is about $78 \%$ (Aslan and Kapdan 2006). The strain of Chlorella sorokiniana has shown high efficiency of removing 31-62.2\% nitrate, 30.6-39.5\% phosphate,54.1-95.1 \% ammonium (Saidu et al. 2017). About 30-100\% of nitrate, ammonia, and phosphate can be removed by immobilized Scenedesmus sp. isolated from municipal wastewater in 21 days (Zhang et al. 2008).For Natural bloom, the efficiency is more than $87 \%$ and $80 \%$ for removing nitrogen and phosphorus respectively (Mennaa et al. 2015). Spirulina maxima show the removal of $87 \%$ nitrogen and $60 \%$ phosphorus at HRT of 4 days (Kosaric et al. 1974). Promising nutrient removal by Spirulina plantensis was also confirmed (Lodi et al. 2003).

The theory of wastewater treatment with microalgae had established around 50 years ago. In most cases, to ensure better wastewater treatment potential, the microalgal strains are chosen considering several criteria. The choice of microalgae depends on Wastewater's properties, the required magnitude of treatment efficiency, the cost, and energy requirement of biomass harvesting, and the application of the harvested biomass (Al-Jabri et al. 2021). These microalgae strains from any laboratory having a controlled atmosphere need high maintenance throughout the operation. Various environmental elements also have a significant impact on them. To minimize these effects, using microalgae from natural blooms in local fish ponds is a potential alternative. 


\section{METHODOLOGY}

\subsection{Natural-Bloom Culture}

Microalgae sample for this study was collected from the natural bloom in pond by the side of university avenue, Shahjalal University of Science and Technology, Sylhet. The collected sample was primarily stored in filtered pond water in a $0.5 \mathrm{~L}$ plastic bottle.Numerous studies showed that the cell size of microalgae is ranged from 1.75 $\mu \mathrm{m}$ to $8 \mu \mathrm{m}$ (Reynolds and Walsby 1975, M et al. 2013, Taghipour Heidari et al. 2018). As a result, in this study, Grade 2 qualitative filter paper with a pore size of $8 \mu \mathrm{m}$ was used. Naturally grown microalgae may arise sporadically as water blooms in ponds. Generally, a large number of these natural blooms are consist of unicellular blue-green algae (Geitler 1932). For this reason, the BG-11 cultural medium has been selected to ensure the growth of microalgae. Medium BG-11 is neutral after sterilization. It supports the growth of the algal population in the air (Stanier et al. 1971). The $\mathrm{pH}$ of the BG-11 culture medium was maintained at 7.1 by using $1 \mathrm{M} \mathrm{NaOH}$. After adjusting the $\mathrm{pH}$, the solution was autoclaved at $121^{\circ} \mathrm{C}$ for $15 \mathrm{~min}$. The medium was cooled before adding the collected microalgae sample. The collected microalgae were separated from pond water by filtration. Then the filtrate was added to a sterilized BG-11 medium in three 1L beakers. Continuous air supply had maintained by using an air pump. A 16:8 hr light:dark cycle was maintained throughout the culture condition. $\mathrm{pH}$ had measured once a day and maintained as 7.1 .

\subsection{Growth Rate Measurement}

A $10 \mathrm{~mL}$ sample from each batch has been collected daily at mid-day. Spectrophotometric analyses of the collected samples are done by using a UV spectrophotometer. Optical density has been measured from the absorbance of $680 \mathrm{~nm}$ wavelength. The optical density indicates the density of microalgae. Using the optical density $\left(\mathrm{OD}_{680}\right)$ the growth rate of microalgae is calculated by using the following exponential formula:

$$
\text { Growth rate, GR (per day) }=\frac{\ln O D_{t}-\ln O D_{0}}{t},
$$

where $\mathrm{OD}_{0}$ represents the optical density at the initial day and $\mathrm{OD}_{\mathrm{t}}$ represents optical density measured at day $\mathrm{t}$ (Wang et al. 2010). After attaining a satisfactory growth rate after 18 days, the mass culture of microalgae has been started. For mass culture, the microalgae were moved from a 1L beaker to a large tank. The dimension of the tank is $60 \mathrm{~cm} \times 20 \mathrm{~cm}$. A total $10 \mathrm{~L}$ BG-11 medium is used for mass culture.

\subsection{Synthetic Wastewater Composition}

Synthetic wastewater is chemically derived wastewater. For determining the chemical composition of the synthetic wastewater, wastewater samples have collected from seven random points. They were selected based on upstream and downstream of canals, residential areas, and reconnaissance surveys. However, the measured nutrient levels of Sylhet municipal wastewater as shown in Table 1 are significantly lower than the standard value. According to the environment conservation rules, 1997 the standards of nitrate, ammonia, and phosphate for inland water surface of Bangladesh are $10 \mathrm{mg} / \mathrm{L}, 50 \mathrm{mg} / \mathrm{L}$, and $35 \mathrm{mg} / \mathrm{L}$ respectively(Rules 1997). As a result, the acquired values had compared to those obtained from the literature review (Table 1). The highest values of nitrate, ammonia, and phosphate were selected for the chemical content of synthetic wastewater. For the chemical composition of synthetic wastewater, the highest nutrient content was selected from Table 1 . The concentration of the nutrients in synthetic wastewater was set as $17 \mathrm{mg} / \mathrm{L}, 100 \mathrm{mg} / \mathrm{L}$, and $212 \mathrm{mg} / \mathrm{L}$ respectively.

Table 1: Nutrient Content of Wastewater

\begin{tabular}{|c|c|c|c|c|c|c|c|c|c|}
\hline \multirow{2}{*}{ Nutrient } & \multicolumn{7}{|c|}{ Samples from Sylhet City [mg/L] } & \multirow{2}{*}{$\begin{array}{l}\text { Concentration in } \\
\text { wastewater }[\mathrm{mg} / \mathrm{L}]\end{array}$} & \multirow[t]{2}{*}{ synthetic } \\
\hline & 1 & 2 & 3 & 4 & 5 & 6 & 7 & & \\
\hline Nitrate & 3.4 & 2.8 & 4.3 & 1.2 & 1.1 & 0.4 & 0.5 & $17^{\mathrm{a}}$ & \\
\hline Ammonia & 21.0 & 4.5 & 9.6 & 22.0 & 1.4 & 20.1 & 16.3 & $100^{\mathrm{b}}$ & \\
\hline Phosphate & 5.3 & 3.5 & 4.5 & 5.7 & 0.9 & 5.4 & 1.3 & $212^{\mathrm{b}}$ & \\
\hline
\end{tabular}

${ }^{\mathrm{a} C h o}$ et al. (2011), ${ }^{\mathrm{b}}$ (Zhou et al. 2012) 


\subsection{Experimental Setup}

The experiments with synthetic wastewater were done on a laboratory scale. For each dose, three 1L solutions of synthetic wastewater were made. The hydraulic retention time (HRT) for all doses remained constant and it was 3 days. As a light source, two 23W fluorescent lights were used (Figure 1(a)). The fluorescent lights had provided 3600 lumens light intensity continuously for the photosynthesis process. To provide turbulence within the wastewater sample, a magnetic stirrer at $350 \mathrm{rpm}$ was used (Figure 1(b)).
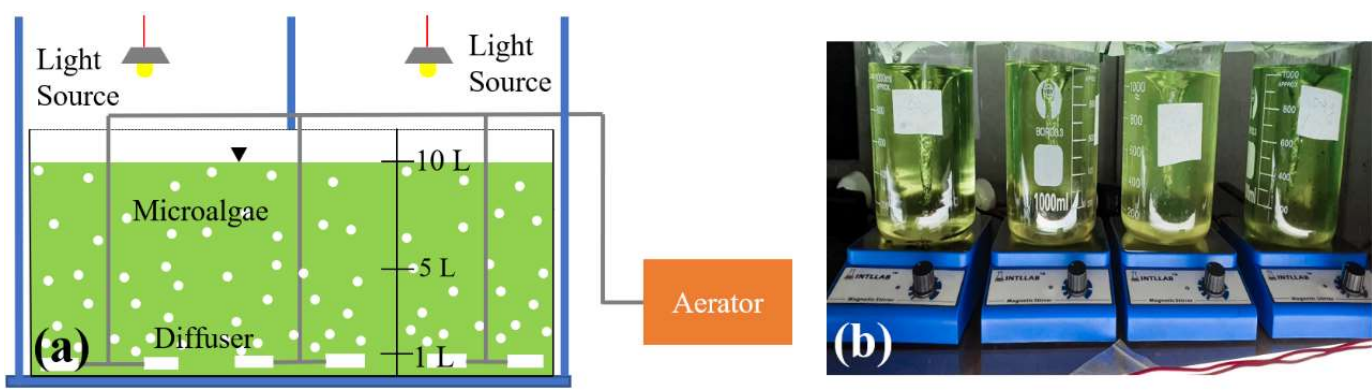

Figure 1: Panel (a) represents the schematic diagram of mass culture of microalgae using $60 \mathrm{~cm} \times 20 \mathrm{~cm}$ tank and Panel (b) represents the experimental setup of synthetic wastewater treatment.

\subsection{Biosorption Modelling}

Nutrient removal by microalgae is a biosorption process. Biosorption is a physicochemical and metabolically independent process. The aim of biosorption modeling is experimental data analyses, understanding process mechanisms, prediction of operational condition changes, and optimizing processes (Fomina and Gadd 2014). For comparison among different types of biosorbents and their capacities of pollutant uptake, the biosorption process can be expressed as an equilibrium isotherm curve (Vijayaraghavan and Yun 2008). For simple single-component models, Langmuir and Freundlich's versions are used widely (Pagnanelli et al. 2002, Gadd 2009) Biosorption modeling helps to develop a design model for the removal of nutrients from wastewater more effectively and accurately. For biosorption modelling, Langmuir (Langmuir 1916) and Freundlich (Freundlich 1906) isotherm models were used in this study.

The initial and final concentrations of nutrients are measured using HACH DR $6000 \mathrm{UV}$ - spectrophotometer. All $\mathrm{HACH}$ products were used according to the manufacturer's instructions. Percentage removal for each compound was calculated using equation 1 (Moris et al. 2018).

$$
\mathrm{Q}_{\mathrm{e}}=\frac{\left(\mathrm{C}_{\mathrm{o}}-\mathrm{C}_{\mathrm{e}}\right)}{C_{o}} \times 100
$$

The characteristic of the Langmuir isotherm is represented by the separation factor RL. RL is a dimensionless constant. $\mathrm{R}_{\mathrm{L}}$ is a dimensionless constant.

$$
\mathrm{R}_{\mathrm{L}}=\frac{1}{1+\mathrm{K}_{\mathrm{L}} \mathrm{C}_{\mathrm{o}}}
$$

The value of $R_{L}>1$ represents the adsorption to be unfavorable. For $R_{L}=1$, the adsorption is linear. For $0<R_{L}<1$, the adsorption is favorable. Lastly, for $\mathrm{R}_{\mathrm{L}}=0$, the adsorption is irreversible (Hamdaoui and Naffrechoux 2007).

The linear form of the Freundlich Isotherm Model (Hill 1946, Hamdaoui and Naffrechoux 2007, Boparai et al. 2011, Liu et al. 2019) for $\log Q_{e}$ vs. $\log C_{e}$ plot is:

$$
\log Q_{e}=\log K_{F}+\frac{1}{n} \log C_{e}
$$

Where, $\mathrm{K}_{\mathrm{F}}$ represents the adsorption capacity $\left[\frac{\boldsymbol{L}}{\boldsymbol{m g}}\right]$ and $\frac{\mathbf{1}}{\boldsymbol{n}}$ represents the Adsorption intensity.

The strength of the used absorbent material is represented by the function $\frac{1}{n}$. The value $\frac{1}{n}>1$ indicates favorable biosorption and $\frac{1}{n}<1$ indicates poor condition (Aziz et al. 2004, Liu et al. 2019). 


\section{RESULT AND DISCUSSION}

\subsection{Growth rate and nutrient removal by Spirulina sp.}

The growth rate of microalgae was measured in terms of $\mathrm{OD}_{680}$. From the growth rate curve, the behavior of microalgae in the culture medium can be stated (Figure 3(a)). No lag phase was observed throughout the curve which indicated the good adaptation of microalgae in the culture medium. An exponential growth phase had observed after 8 days of culture. The exponential growth phase remained for 1 day, and thereafter a comparatively stationary growth phase had achieved.

After reaching the constant growth rate, the collected microalgae had cultured in the glass tank of Figure 1(a) for mass production. After two months of culture, the colonies were observed under a microscope and photographed with a lens of $40 \mathrm{X}$ magnification for taxonomic identification. The dominant algae found in the culture was Spirulina sp.(Figure 2). The Spirulina sp. were identified taxonomically according to Ciferri and Tomasseli (Ciferri 1983, Tomaselli 1997, Rout 2013).

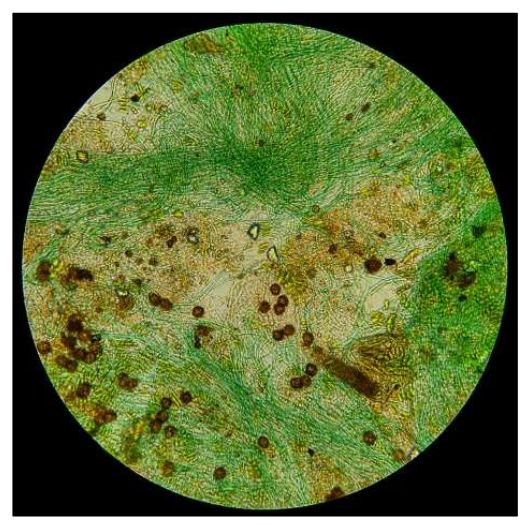

Figure 2: Microscopic Photograph of Spirulina sp. (Magnification 40X)

Removal of nitrate, ammonia and phosphate from municipal wastewater is a vital issue for saving the natural water source from pollution. This study was conducted to reducethe maximum amount of nutrient enrichments within 3 days of HRT. A total of ten different algal doses i.e. 0.2, 0.4, 0.8, 1.0, 1.2, 1.4, 1.6, 1.8, 2.0, and 2.5 g/L were added. Algae were added as a suspension with a ratio of 1:9.5 dry weight (DW) to fresh weight (FW). Figure 3 (b) shows that the maximum reduction in nitrate, ammonia, and phosphate was about $66 \%, 30 \%$, and $54 \%$ respectively for $2.5 \mathrm{~g} / \mathrm{L}$ algal dose. As from Figure 3(a), it can be seen that the algal growth in BG-11 medium for the first 5-6 days is very slow and according to another study, algal growth in wastewater is negligible before 5-6 days (Kothari et al. 2012). As a result, the algal growth rate was not investigated during the nutrient removal from wastewater.
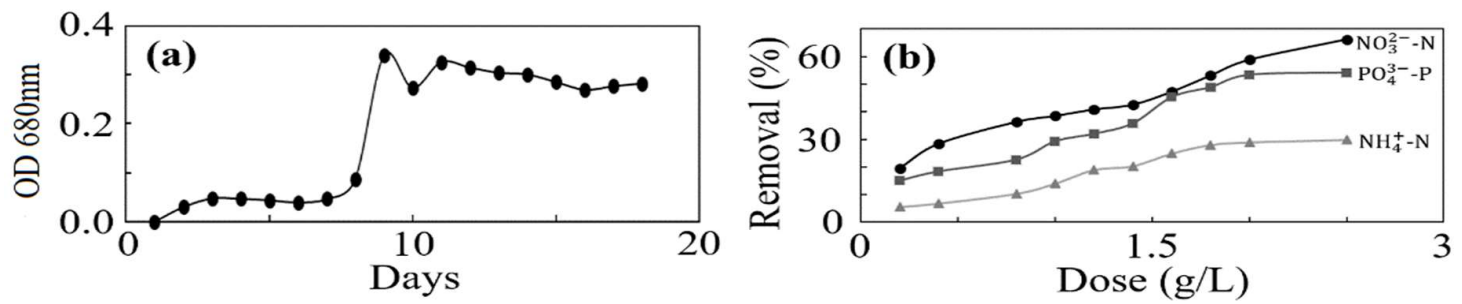

Figure 3: Growth Rate of Spirulina sp. and its efficiency to remove nutrients from wastewater.

\subsection{Calibration results}

Langmuir isotherm model expresses the monolayer adsorption on the adsorbent. The essential characteristic of the model is expressed by the dimensionless constant $R_{L}$. For all three nutrients, the values of $R_{L}$ are within the range $0<\mathrm{R}_{\mathrm{L}}<1$ (Table 2). Therefore, the biosorption of the nutrients can be considered as favorable and the values of $\mathrm{R}^{2}$ and NRMSE also represent the data are well fitted in the model (see Figure 4(a-b)). 

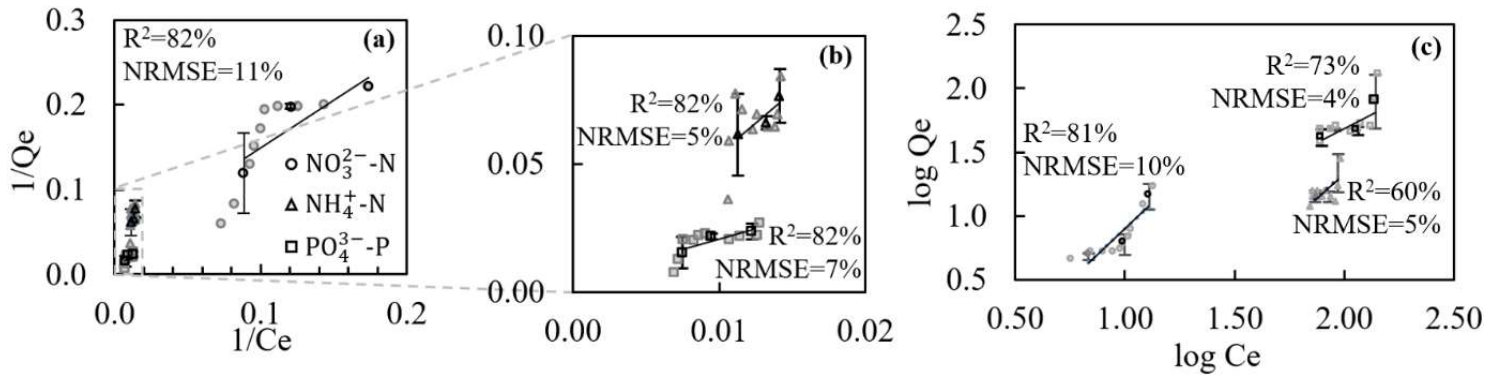

Figure 4: Graphical representation of Langmuir and Freundlich Isotherm Models. Panel (a) and (b) represents Langmuir model, where Panel (a) includes all three nutrients and Panel (b) represents the magnified section of Panel (a). Panel (c) represents Freundlich model.

Freundlich isotherm model supports the surface heterogeneity. The parameters $\mathrm{K}_{\mathrm{F}}$ and $1 / \mathrm{n}$ from this model express the adsorption capacity $(\mathrm{L} / \mathrm{mg})$ and adsorption intensity respectively. Figure 4(c) shows the values of $\mathrm{R}^{2}$ and NRMSE are around $60-80 \%$ and 3-10\% respectively which represents the sound goodness of fit of the modeled data. The values of $1 / \mathrm{n}$ for all nutrients are seen to be greater than unity (Table 2), which symbolizes the increment of absorption coefficient with the increment of solution concentration. As a result, hydrophobic surface characteristics increase after the monolayer. Again, the value of $1 / \mathrm{n}$ within the range of 1-10 expresses the favourability of the biosorption for all components.

Table 2: Calibrated values of both Langmuir and Freundlich model parameters.

\begin{tabular}{llllll}
\hline Parameters & $\mathbf{1} / \mathbf{Q}_{\mathbf{m}}$ & $\mathbf{K}_{\mathbf{L}}$ & $\mathbf{R}_{\mathbf{L}}$ & $\log _{\mathbf{F}}$ & $\mathbf{1 / n}$ \\
\hline Nitrate & 0.036 & 0.033 & 0.64 & -0.71 & 1.61 \\
Ammonia & 0.006 & 0.001 & 0.89 & -1.73 & 1.53 \\
Phosphate & 0.004 & 0.003 & 0.79 & -0.24 & 1 \\
\hline
\end{tabular}

\section{CONCLUSION}

In this study, the BG-11 culture medium is used for the mass production of the collected natural bloom. After obtaining the dominant species, the microalgae doses of $0.2 \mathrm{~g} / \mathrm{L}, 0.4 \mathrm{~g} / \mathrm{L}, 0.6 \mathrm{~g} / \mathrm{L}, 0.8 \mathrm{~g} / \mathrm{L}, 1.0 \mathrm{~g} / \mathrm{L}, 1.2 \mathrm{~g} / \mathrm{L}, 1.4$ $\mathrm{g} / \mathrm{L}, 1.6 \mathrm{~g} / \mathrm{L}, 1.8 \mathrm{~g} / \mathrm{L}, 2.0 \mathrm{~g} / \mathrm{L}$, and $2.5 \mathrm{~g} / \mathrm{L}$ are added from mass culture into $1 \mathrm{~L}$ synthetic wastewater. The hydraulic retention time for all algal doses is maintained as 3 days.

The microalgae Spirulina platensis reduced ammonia nutrients by $82 \%$ and phosphate by $65.2 \%$ within the time period of $48 \mathrm{hrs}$ having initial concentrations of $10 \mathrm{mg} / \mathrm{L}$ and $5 \mathrm{mg} / \mathrm{L}$ respectively (Sofiyah and Suryawan 2021). Higher Yields can be obtained by another study with a residence time of 10 days, ammonia removal by Spirulina platensis was $97.8 \%$ and phosphate has $64.5 \%$ reduction (Kun et al. 2010). In another study, the Spirulina platensis was cultured in a $75 \%$ wastewater medium for 20 days. the percent reduction in the level of nitrate, phosphate, and ammonium in the medium was $99 \%, 99 \%$, and $99 \%$, respectively (Can et al. 2015). In this study, the maximum removal of nitrate, ammonia, and phosphate by Spirulina $s p$. are $66 \%$, 30\%, and $54 \%$ respectively which is much lower than the other studies. These results have been obtained for 3-day HRT. The maximum nutrient removal has been found at a $2.5 \mathrm{~g} / \mathrm{L}$ algal dose.

The feasibility of this biosorption treatment with Spirulina sp.was also confirmed by the Langmuir and Freundlich isotherm models. In both cases, the separation factor and the adsorption intensity are below unity. Therefore, not only has the favorable adsorption of nitrate, ammonia, and phosphate has established but also well goodness of fit of both models have been established by blue-green algae Spirulina sp.

However, after treating the wastewater with $2.5 \mathrm{~g} / \mathrm{L}$ algal dose for 3 days, the remaining amount of nitrate, ammonia, and phosphate in the synthetic wastewater are $6 \mathrm{mg} / \mathrm{L}, 70 \mathrm{mg} / \mathrm{L}$, and $97.5 \mathrm{mg} / \mathrm{L}$ respectively. The amount of remaining nutrients is more than the standard value determined by the environment conservation rules, 1997 for both ammonia and phosphate. Therefore, a higher algal dose is required to obtain the desired removal rate in 3 daysof HRT. 


\section{ACKNOWLEDGEMENTS}

We, gratefully, acknowledge, Mohammad Amzad Hossain, Assistant Professor, Dept. of Fish Biology and Genetics, Sylhet Agriculture University, Sylhet for helping to determine microalgae species. This is to declare that a part of this paper has been presented in ICCESD 2020 conference.

\section{REFERENCES}

Abdel-Raouf, N., A. Al-Homaidan and I. Ibraheem (2012). "Microalgae and wastewater treatment." Saudi journal of biological sciences19(3): 257-275.

Abel, P. D. (2014). Water pollution biology, CRC Press.

Al-Jabri, H., P. Das, S. Khan, M. Thaher and M. AbdulQuadir (2021). "Treatment of Wastewaters by Microalgae and the Potential Applications of the Produced Biomass-A Review." Water13(1): 27.

Arbib, Z., J. Ruiz, P. Álvarez-Díaz, C. Garrido-Pérez and J. A. Perales (2014). "Capability of different microalgae species for phytoremediation processes: Wastewater tertiary treatment, $\mathrm{CO} 2$ bio-fixation and low cost biofuels production." Water Research49: 465-474.

Aslan, S. and I. K. Kapdan (2006). "Batch kinetics of nitrogen and phosphorus removal from synthetic wastewater by algae." Ecological Engineering28(1): 64-70.

Aziz, H. A., M. S. Yusoff, M. N. Adlan, N. H. Adnan and S. Alias (2004). "Physico-chemical removal of iron from semi-aerobic landfill leachate by limestone filter." Waste management24(4): 353-358.

Barsanti, L. and P. Gualtieri (2014). Algae: anatomy, biochemistry, and biotechnology, CRC press.

Barth, E., J. Smith, C. Brunner and J. Farrell (1976). "Process design manual for phosphorus removal." US Environ. Protection Agency Report EPA625: 1-76.

Beuckels, A., E. Smolders and K. Muylaert (2015). "Nitrogen availability influences phosphorus removal in microalgae-based wastewater treatment." Water Research77: 98-106.

Blier, R., G. Laliberte and J. De la Noüe (1995). "Tertiary treatment of cheese factory anaerobic effluent with Phormidium bohneri and Micractinum pusillum." Bioresource Technology52(2): 151-155.

Boparai, H. K., M. Joseph and D. M. O’Carroll (2011). "Kinetics and thermodynamics of cadmium ion removal by adsorption onto nano zerovalent iron particles." Journal of Hazardous Materials186(1): 458-465.

Borowitzka, M. A. (2013). "High-value products from microalgae — their development and commercialisation." Journal of Applied Phycology25(3): 743-756.

Cai, T., S. Y. Park and Y. Li (2013). "Nutrient recovery from wastewater streams by microalgae: status and prospects." Renewable and Sustainable Energy Reviews 19: 360-369.

Can, Ş. S., V. Demir and E. Can (2015). "Evaluating the dilution of municipal wastewater on biomass increase, lipid production and nutrient removal by the blue-green algae Spirulina platensis (Geitler)." Fresenius Environmental Bulletin24(3): 904-909.

Carpenter, S. R., N. F. Caraco, D. L. Correll, R. W. Howarth, A. N. Sharpley and V. H. Smith (1998). "Nonpoint pollution of surface waters with phosphorus and nitrogen." Ecological applications8(3): 559-568.

Cho, S., T. T. Luong, D. Lee, Y.-K. Oh and T. Lee (2011). "Reuse of effluent water from a municipal wastewater treatment plant in microalgae cultivation for biofuel production." Bioresource Technology 102(18): 86398645 .

Ciferri, O. (1983). "Spirulina, the edible microorganism." Microbiological reviews47(4): 551.

Colak, O. and Z. Kaya (1988). "A study on the possibilities of biological wastewater treatment using algae." Doga Biyoloji Serisi12: 18-29.

Commission, E. (2002). "Commission Decision 2002/657/EC of 12 August 2002 implementing Council Directive 96/23/EC concerning the performance of analytical methods and the interpretation of results." Off J Eur Comm221: 8-36.

De la Noüe, J. and A. Basseres (1989). "Biotreatment of anaerobically digested swine manure with microalgae." Biological wastes29(1): 17-31.

Fomina, M. and G. M. Gadd (2014). "Biosorption: current perspectives on concept, definition and application." Bioresource Technology160: 3-14.

Freundlich, H. (1906). "Over the adsorption in solution." J. Phys. Chem57(385471): 1100-1107.

Gadd, G. M. (2009). "Biosorption: critical review of scientific rationale, environmental importance and significance for pollution treatment." Journal of Chemical Technology \& Biotechnology: International Research in Process, Environmental \& Clean Technology84(1): 13-28.

Gao, F., C. Li, Z. H. Yang, G. M. Zeng, J. Mu, M. Liu and W. Cui (2016). "Removal of nutrients, organic matter, and metal from domestic secondary effluent through microalgae cultivation in a membrane photobioreactor." Journal of Chemical Technology \& Biotechnology91(10): 2713-2719. 
Geitler, L. (1932). "Cyanophyceae." Kryptogramenflora von Deutschland, Osterreich und der Schweiz14: 130148.

Ghafari, S., M. Hasan and M. K. Aroua (2008). "Bio-electrochemical removal of nitrate from water and wastewater-a review." Bioresource Technology99(10): 3965-3974.

Hamdaoui, O. and E. Naffrechoux (2007). "Modeling of adsorption isotherms of phenol and chlorophenols onto granular activated carbon: Part I. Two-parameter models and equations allowing determination of thermodynamic parameters." Journal of Hazardous Materials147(1): 381-394.

Henze, M., P. Harremoes, J. la Cour Jansen and E. Arvin (2001). Wastewater treatment: biological and chemical processes, Springer Science \& Business Media.

Hill, T. L. (1946). "Statistical mechanics of multimolecular adsorption II. Localized and mobile adsorption and absorption." The Journal of Chemical Physics14(7): 441-453.

Jais, N. M., R. M. S. R. Mohamed, A. A. Al-Gheethi and M. K. A. Hashim (2017). "The dual roles of phycoremediation of wet market wastewater for nutrients and heavy metals removal and microalgae biomass production." Clean Technologies and Environmental Policy 19(1): 37-52.

Klaassen, C. D. and M. O. Amdur (2013). Casarett and Doull's toxicology: the basic science of poisons, McGrawHill New York.

Kosaric, N., H. Nguyen and M. Bergougnou (1974). "Growth of Spirulina maxima algae in effluents from secondary waste-water treatment plants." Biotechnology and Bioengineering 16(7): 881-896.

Kothari, R., V. V. Pathak, V. Kumar and D. Singh (2012). "Experimental study for growth potential of unicellular alga Chlorella pyrenoidosa on dairy waste water: an integrated approach for treatment and biofuel production." Bioresource Technology116: 466-470.

Kun, H., H. Zhi and Z. Wenjie (2010). "Purification of domestic wastewater by Spirulina platensis." Environmental Pollution \& Control2.

Langmuir, I. (1916). "The constitution and fundamental properties of solids and liquids. Part I. Solids." Journal of the American chemical society38(11): 2221-2295.

Lau, P., N. Tam and Y. Wong (1997). "Wastewater nutrients (N and P) removal by carrageenan and alginate immobilized Chlorella vulgaris." Environmental technology18(9): 945-951.

Lavrinovičs, A. and T. Juhna (2017). "Review on Challenges and Limitations for Algae-Based Wastewater Treatment." Construction Science20: 17-25.

Liu, L., X.-B. Luo, L. Ding and S.-L. Luo (2019). 4 - Application of Nanotechnology in the Removal of Heavy Metal From Water. Nanomaterials for the Removal of Pollutants and Resource Reutilization. X. Luo and F. Deng, Elsevier: 83-147.

Lodi, A., L. Binaghi, C. Solisio, A. Converti and M. Del Borghi (2003). "Nitrate and phosphate removal by Spirulina platensis." Journal of Industrial Microbiology and Biotechnology30(11): 656-660.

M, S., G. Prochazkova, L. Kyselová, K. Z and T. Brányik (2013). "Adhesion of Chlorella vulgaris to solid surfaces, as mediated by physicochemical interactions." Journal of Applied Phycology 25.

Mallick, N. (2002). "Biotechnological potential of immobilized algae for wastewater N, P and metal removal: A review." Biometals15(4): 377-390.

Martinez, M., J. Jimenez and F. El Yousfi (1999). "Influence of phosphorus concentration and temperature on growth and phosphorus uptake by the microalga Scenedesmus obliquus." Bioresource Technology67(3): 233-240.

Martínez, M. E., S. Sánchez, J. M. Jiménez, F. El Yousfi and L. Muñoz (2000). "Nitrogen and phosphorus removal from urban wastewater by the microalga Scenedesmus obliquus." Bioresource Technology73(3): 263-272.

Mayo, A. W. and E. E. Hanai (2014). "Dynamics of nitrogen transformation and removal in a pilot high rate pond."

Mennaa, F. Z., Z. Arbib and J. A. Perales (2015). "Urban wastewater treatment by seven species of microalgae and an algal bloom: biomass production, $\mathrm{N}$ and $\mathrm{P}$ removal kinetics and harvestability." Water Research83: 42-51.

Molinos-Senante, M., F. Hernández-Sancho and R. Sala-Garrido (2010). "Economic feasibility study for wastewater treatment: A cost-benefit analysis." Science of The Total Environment408(20): 4396-4402.

Moris, S., G. Garcia-Cabellos, D. Enright, D. Ryan and A.-M. Enright (2018). "Bioremediation of landfill leachate using isolated bacterial strains." Int. J. Environ. Bioremed. Biodegrad.6(1): 26-35.

Olguín, E. J. (2012). "Dual purpose microalgae-bacteria-based systems that treat wastewater and produce biodiesel and chemical products within a Biorefinery." Biotechnology Advances30(5): 1031-1046.

Olguín, E. J. (2003). "Phycoremediation: key issues for cost-effective nutrient removal processes." Biotechnology Advances22(1-2): 81-91.

Pagnanelli, F., A. Esposito and F. Vegliò (2002). "Multi-metallic modelling for biosorption of binary systems." Water Research36(16): 4095-4105.

Pittman, J. K., A. P. Dean and O. Osundeko (2011). "The potential of sustainable algal biofuel production using wastewater resources." Bioresource Technology102(1): 17-25. 
Proulx, D. and J. De la Noue (1988). "Removal of macronutrients from wastewaters by immobilized microalgae." Moo-Young (ed.), Bioreactor Immobilized Enzimes and Cells. Fundamentals and Applications. Elsevier Applied Science Publ. Ltd., Essex.

Reynolds, C. and A. Walsby (1975). "Water-blooms." Biological reviews50(4): 437-481.

Rout, N. P. (2013). "Isolation, Identification and Germplasm Preservation of Different Native Spirulina Species from Western Mexico." American Journal of Plant Sciences4: 65-71.

Rules, E. C. (1997). "Department of Environment." Ministry of Environment and Forest. People’s Republic of Bangladesh.

Saidu, H., H. Jamaluddin and S. E. Mohamad (2017). "Nutrient removal and biokinetic study of freshwater microalgae in palm oil mill effluent (POME)." Indian Journal of Science and Technology 10(24): 1-10.

Sofiyah, E. S. and I. W. K. Suryawan (2021). "Cultivation of Spirulina platensis and Nannochloropsis oculata for nutrient removal from municipal wastewater." Rekayasa14(1): 93-97.

Stanier, R. Y., R. Kunisawa, M. Mandel and G. Cohen-Bazire (1971). "Purification and properties of unicellular blue-green algae (order Chroococcales)." Bacteriological reviews35(2): 171-205.

Sturm, B. S. and S. L. Lamer (2011). "An energy evaluation of coupling nutrient removal from wastewater with algal biomass production." Applied Energy88(10): 3499-3506.

Suryawan, I. W. K. and E. S. Sofiyah (2020). "Cultivation of chlorella sp. and algae mix for NH3-N and PO4-P domestic wastewater removal." Civil and Environmental Science Journal (Civense)3(1): 31-36.

Taghipour Heidari, A., K. Haddadi, R. Gheshlaghi and M. A. Mahdavi (2018). Investigation the effect of light perturbation on Chlorella vulgaris IG-R-96 microalgae growth using artificially illuminated PBRs.

Talbot, P. and J. De la Noüe (1993). "Tertiary treatment of wastewater with Phormidium bohneri (Schmidle) under various light and temperature conditions." Water Research27(1): 153-159.

Tomaselli, L. (1997). "Morphology, ultrastructure and taxonomy of Arthrospira (Spirulina) maxima and Arthrospira (Spirulina) platensis." Spirulina platensis (Arthrospira): physiology, cell-biology and biotechnology: 1-16.

Vijayaraghavan, K. and Y.-S. Yun (2008). "Bacterial biosorbents and biosorption." Biotechnology Advances26(3): 266-291.

Wang, J.-H., T.-Y. Zhang, G.-H. Dao, X.-Q. Xu, X.-X. Wang and H.-Y. Hu (2017). "Microalgae-based advanced municipal wastewater treatment for reuse in water bodies." Applied Microbiology and Biotechnology101(7): 2659-2675.

Wang, L., M. Min, Y. Li, P. Chen, Y. Chen, Y. Liu, Y. Wang and R. Ruan (2010). "Cultivation of green algae Chlorella sp. in different wastewaters from municipal wastewater treatment plant." Applied biochemistry and biotechnology162(4): 1174-1186.

Whitton, R., F. Ometto, M. Pidou, P. Jarvis, R. Villa and B. Jefferson (2015). "Microalgae for municipal wastewater nutrient remediation: mechanisms, reactors and outlook for tertiary treatment." Environmental Technology Reviews4(1): 133-148.

Wu, Y.-H., Y. Yu, X. Li, H.-Y. Hu and Z.-F. Su (2012). "Biomass production of a Scenedesmus sp. under phosphorous-starvation cultivation condition." Bioresource Technology 112: 193-198.

Zhang, E., B. Wang, Q. Wang, S. Zhang and B. Zhao (2008). "Ammonia-nitrogen and orthophosphate removal by immobilized Scenedesmus sp. isolated from municipal wastewater for potential use in tertiary treatment." Bioresource Technology 99(9): 3787-3793.

Zhou, W., M. Min, Y. Li, B. Hu, X. Ma, Y. Cheng, Y. Liu, P. Chen and R. Ruan (2012). "A heterophotoautotrophic two-stage cultivation process to improve wastewater nutrient removal and enhance algal lipid accumulation." Bioresource Technology110: 448-455.

(C) 2021 JES. Journal of Engineering Science published by Faculty of Civil Engineering, Khulna University of Engineering \& Technology. This is an open access article under the terms of the Creative Commons Attribution-NonCommercialNoDerivatives License, which permits use and distribution in any medium, provided the original work is properly cited, the use is non-commercial and no Modifications or adaptations are made. 